\title{
Opportunities of short-term weather forecasts data in the environmental monitoring of the Kazakhstan
}

\author{
Alexey Terekhov ${ }^{1,2^{*}}$, Nurlan Abayev ${ }^{2,3}$, Kainar Bolatov ${ }^{2,3}$, Zaure Egemberdyeva ${ }^{1,4}$, \\ ${ }^{1}$ Institute of information and computing technologies MES, Almaty, 050010 Kazakhstan \\ 2 RSE "Kazhydromet", Almaty, 050022, Kazakhstan \\ ${ }^{3}$ al-Farabi Kazakh national University, Almaty, 050040, Kazakhstan \\ ${ }^{4}$ Almaty University of Power Engineering and Telecommunications, Almaty, 050013, Kazakhstan
}

\begin{abstract}
This paper considers the possibilities of assimilation of FEWS NET (Famine early Warning System Network) products in natural resource monitoring of the territory of Kazakhstan in the cold period. With an area of 2.7 million $\mathrm{km}^{2}$, Kazakhstan is located in the center of Eurasia in the arid zone, and snow is one of the most important water sources in the first half of the vegetation season. The products "Snow Depth", "Temperature" and "Precipitation " developed for Central Asia are based on model meteorological data, including short-term weather forecasts. This information, presented in the form of regular matrices, has several advantages in efficiency and spatial detailing over direct ground (remote) measurements of meteorological parameters. The use of FEWS NET products for the environmental monitoring of the entire territory of Kazakhstan or its separate parts is of benefit for assessing the current situation on snow reserves, weather regimes and prospects for spring snowmelt.
\end{abstract}

\section{Introduction}

At present, the weather forecast is a highly demanded and developed area of information processing, in which huge estimated capacities are involved. The vast amounts of data from a developed network of ground-based meteorological stations and satellitebased sensing information are analyzed. To assimilate this information, a large number of models have been developed that describe and predict the main weather characteristics of the underlying surface of the Earth with different space-time scales [1,2]. As a result, the relevance of weather forecasts, especially short-term forecasts, is quite high. Predictive data of meteorological parameters have the format of regular matrices with a characteristic period of one kilometer and above. In the current information flow scheme, actual (groundbased and satellite) monitoring of the state of the underlying surface of the Earth is significantly inferior in regularity and information saturation to the model characteristics

* Corresponding author: aterekhov1@yandex.ru 
based on short-term meteorological forecasts. This circumstance provides the basis for the creation of systems of natural resource territorial monitoring, based on short-term meteorological forecasting data, opening for them a new important and popular application.

The calculated model data of meteorological characteristics are available for free on various portals. The largest of them are global data assimilation systems [3,4], such as the GDAS (Global Data Assimilation System [https://www.ncdc.noaa.gov]), LDAS (Land Data Assimilation System). There are the regional products. Famine Early Warning System Network (FEWS NET) [https://earlywarning.usgs.gov/fews/overview] administers such activity for some regions in Africa, Asia, and Latin America.

The arid climate of Central Asia, including Kazakhstan, makes this territory very dependent on winter snow accumulation [5]. Snow is an important water resource, which provides the following: activity of spring floods [6]; humidification of arable land in the first half of the growing season and accordingly parameters affecting the state of vegetation cover and the yield of grain crops on the rain-fed agriculture [7-9]. The volume of runoff of large rivers of the region (River Ile, River Kara-Ertis) and the work of the hydraulic units located in transboundary river basins [10-11] is significantly affected by the snow accumulation in mountain conditions (the territory of Kazakhstan includes parts of Tien Shan, Jungarian Alatau and Altai). The purpose of this work is to demonstrate the capabilities of natural resource monitoring of the territory of Kazakhstan in the cold period, based on FEWS NET products.

\section{Test site territory}

Kazakhstan is the largest country in Central Asia. (an area of 2.72 million $\mathrm{km}^{2}$, the 9th place in the world), fig. 1. The country is located in the center of Eurasia and has no access to an ocean. The climate is mainly arid, sharply continental. Almost half of the country's territory is semi-deserts and deserts climatic zones. The very low population density $(6,8$ people $\mathrm{km}^{2}, 184^{\text {th }}$ in the world) makes it very important to develop natural resource monitoring systems for the widest possible list of parameters.
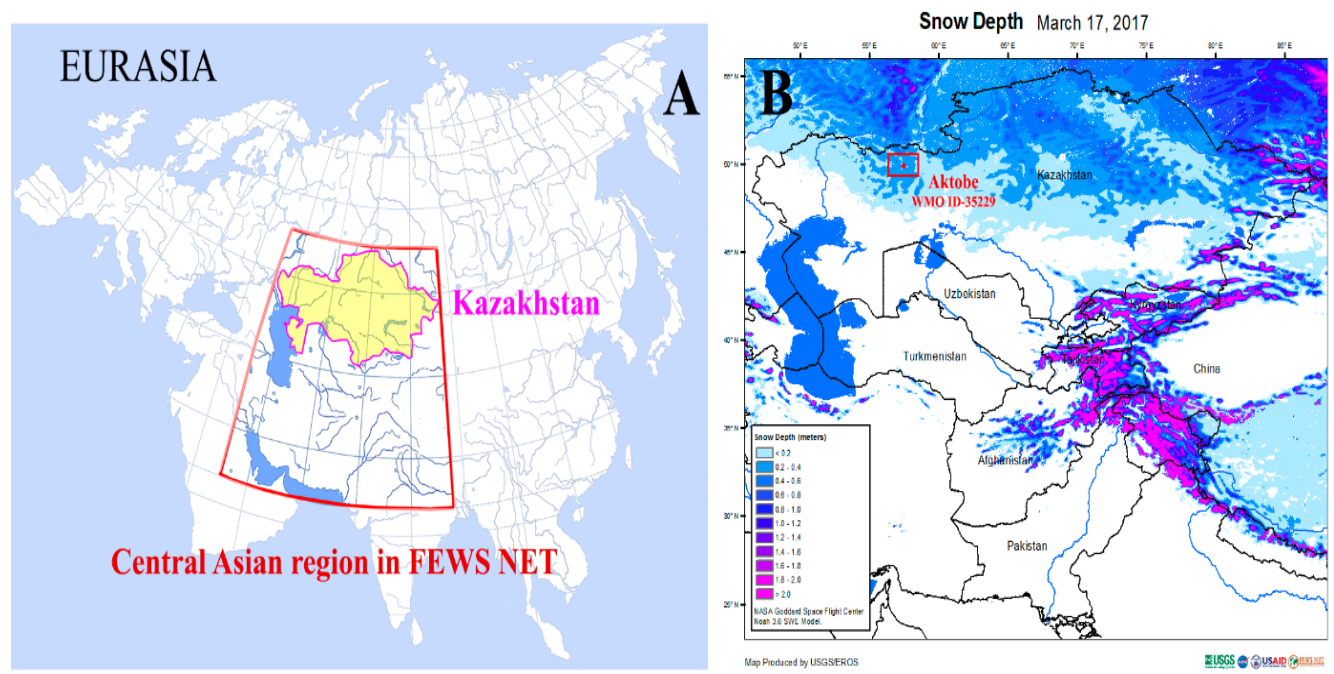

Fig. 1. A - Disposition of Central Asian region (FEWS NET) and Kazakhstan on Eurasia continent; B - example of daily "Snow Depth" map for Central Asia from FEWS NET with disposition meteorological station Aktobe, Kazakhstan. 


\section{Materials and methods}

FEWS NET portal products presented for the Central Asia region (CA) were used as raw data. Three products are of the greatest practical interest in monitoring the territory of Kazakhstan during the cold period which are "Snow Depth (SD)", (fig.1b); "Temperature $(\mathrm{T})$ "; "Precipitation (P)". These options are available as overview maps in geographic projection, (Lat/Lon) in "png" file format. For the SD product, the spatial resolution is $0.044^{\circ} \times 0.044^{\circ}$, with a daily update. Products " $\mathrm{T}$ "and" $\mathrm{P}$ " have a spatial resolution of $0.1423^{\circ} \times 0.1423^{\circ}$, with a ten days update. The depth of the SD archive linked to Terra MODIS satellite data is 20 years: From October 2000 to the present. The remaining products ("T" and "P") are available since 2013.

The ten-day product "Temperature" is an averaging of 6-hour forecasts of air temperature (at a height of $2 \mathrm{~m}$ ). Map of deviations of the current temperature from the climate norm, which is constructed as a difference between the current values of ten-day temperature and the data of ground weather stations 1960-1990 is also interesting.

The ten-day value of the product "Precipitation" is calculated within the framework of the RFE (Rainfall Estimation) ver.2.0 from the NOAA Climate Prediction Center (CPC). The daily rainfall estimation is based on various satellite data and is adjusted according to the WMO ground network of weather stations. Daily estimates are aggregated to ten-day values.

\section{Results}

RSE "Kazhydromet" has been producing a ten-day pilot report titled "Snow coverage of Kazakhstan" since 2018. The report describes the weather conditions and characteristics of the snow coverage during the cold period, from November 1 to April 30. In the season of 2019-2020, the report is based on the FEWS NET products "Snow Depth", "Temperature", "Precipitation". The Figure 2c, 3 show the sample illustrations from report (No 3) of $30^{\text {th }}$ of November, 2019.

\section{Validation}

In their development and application, short-term forecast meteorological products underwent numerous validation procedures that demonstrated their high accuracy. Validation of snow height for the territory of Central Asia is fragmentary. For the territory of Kazakhstan, there is information on validation for the zone of dry steppes and semideserts, which shows a good correspondence between "Snow Depth" and ground measurements [12], fig.2 (a,b).

\section{Discussion}

The overview presented in the report "Snow coverage of Kazakhstan" is of significant interest, fig.(2c,3). Since the data from meteorological stations, is relatively small, and because of the variability of climatic conditions of their locations (often foothills), the data cannot be formed in a comparable product in terms of efficiency and information provision. The existing data archive allows us to use not only absolute but also relative assessments, which increases the accuracy of estimations. The subsequent processing of FEWS NET 
products for the purpose of monitoring the conditions of spring floods, which pose a real threat to the economic facilities and population of Kazakhstan, may become a promising direction.

\section{Conclusion}

Fields of the short-term forecast of meteorological parameters and data obtained using various meteorological models can be used as a basis for monitoring of natural resources of the territory of Kazakhstan, characterized by extremely low population density. The efficiency and information content of such products is much higher than the data of ground (remote) monitoring of environmental parameters. The use of relative estimates based on existing model information archives with a depth of up to 20 years reduces the importance of absolute errors and opens up new opportunities for monitoring practically important and/or dangerous phenomena, such as spring floods.
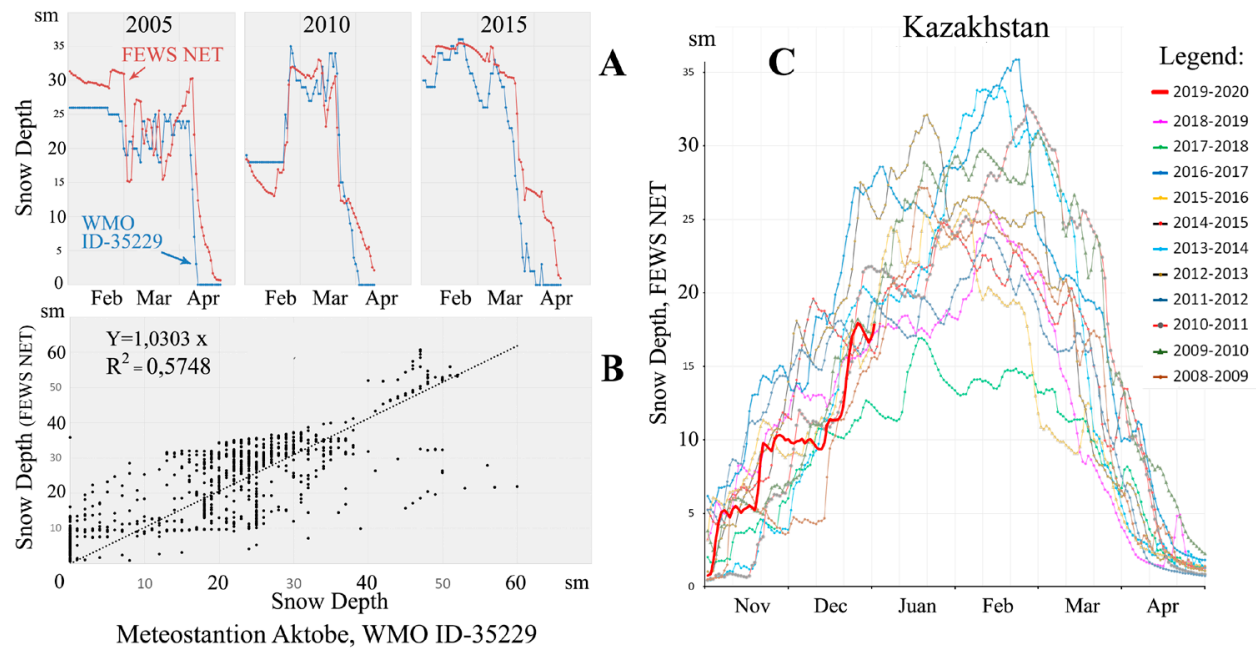

Fig. 2. A - Snow depth evolution during February - April for 2005, 2010 and 2015 years. Comparison meteorological station (Aktobe, WMO ID-35229) data with FEWS NET "SD" product.

B -Comparison snow depth daily data during February-April 2005-2019 years. Ground data (Aktobe station) vs FEWS NET "Snow Depth" product (averaging zone 150x130 km around meteorological station Aktobe. C - Seasonal dynamics of "Snow Depth" for territory of Kazakhstan create on base of daily "SD" data from FEWS NET. 


\section{Central Asia Dekadal Precipitation and Anomalies}
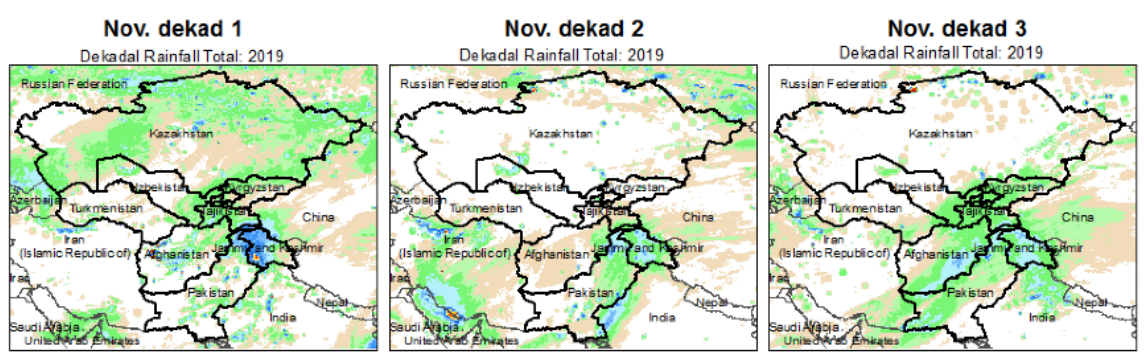

2019

NOAA

RFE-2)

Dekadal Difference from Average

Dekadal Difference from Average

Dekadal Difference from Average
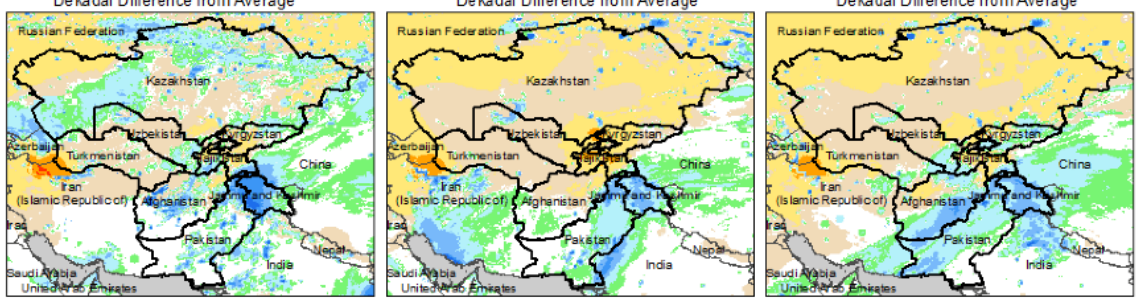

$\mathrm{RF}(\mathrm{mm})$

$\square 0-1$

$5-10$

$25-50$
$50-75$

$75-100$

$100-150$

$\square 150-200$

$200-250$
$250-350$

\section{Central Asia Dekadal Temperature and Anomalies}
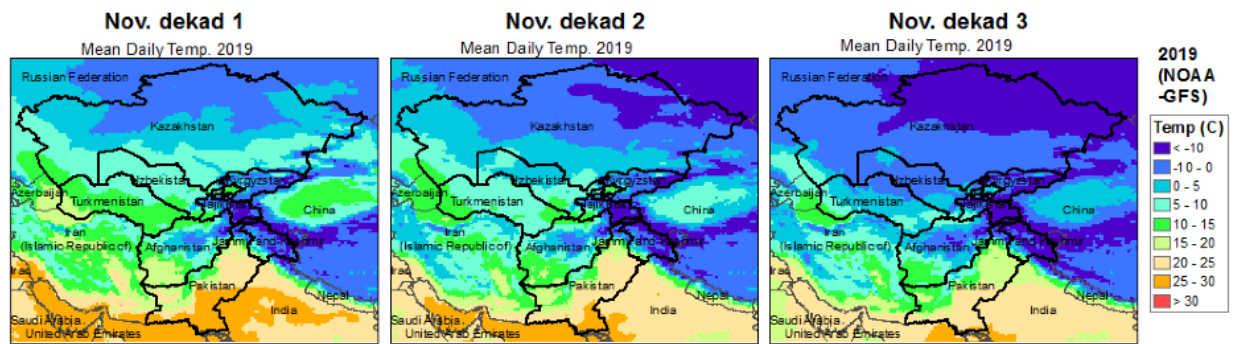

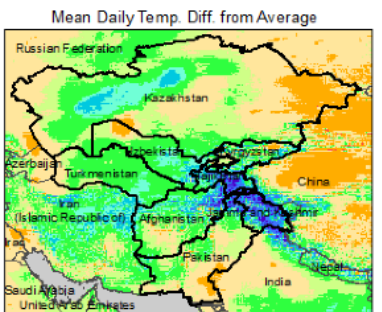

Map produced by USGS/EROS

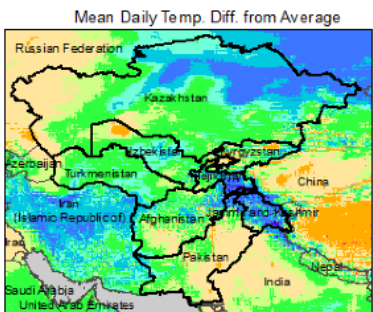

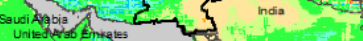

Fig. 3. Example of "Temperature" and "Precipitation" monitoring on base of decadal FEWS NET products (November, 2019).

\section{Acknowledgment}

This work was financially supported by Ministry of Education and Sciences of Kazakhstan, grant AP05134241. 


\section{References}

1. T. N. Krishnamurti, C. M. Kishtawal,T. E. LaRow, D. R. Bachiochi, Z. Zhang, C. E. Williford, S. Gadgil, S. Surendran, Improved Weather and Seasonal Climate Forecasts from Multimodel Superensemble, Science, 1999, Vol. 285, Issue 5433, pp.1548-1550, DOI: $10.1126 /$ science.285.5433.1548.

2. T. N. Krishnamurti, C. M. Kishtawal, Z. Zhang, T. LaRow, D. Bachiochi, E. Williford, S. Gadgil, S. Surendran, Multimodel Ensemble Forecasts for Weather and Seasonal Climate, J. Clim., 2000, Vol. 13, No. 23, pp. 4196-4216, DOI: 10.1175/15200442(2000)013<4196.

3. L. Bengtsson, M. Ghil, E. Kallen, Dynamic Meteorology: Data Assimilation Methods, New York: Springer, 2012, 330 p, DOI: 10.1007/978-1-4612-5970-1.

4. W. Lahoz, B. Khttatov, R. Menard, Data Assimilation: Making Sense of Observations, Heildelberg: Springer; 2010, 718 p, DOI: 10.1007/978-3-540-74703-1.

5. A. G. Terekhov, N. N. Abayev, N. R. Yunicheva, Anomalous snowy regime at 2019 year and long-term trends in snow depth in Kazakhstan, Sovremennye problemy distantsionnogo zondirovaniya Zemli iz kosmosa, 2019, Vol. 16, No. 5, pp. 351-355, DOI: 10.21046/2070-7401-2019-16-5-351-355.

6. A. G. Terekhov, I. T. Pak, S. A. Dolgikh, Satellite observations of the anomalous spring flood at the lower reach of the Ayaguz river in 2016, Sovremennye problemy distantsionnogo zondirovaniya Zemli iz kosmosa, 2016, Vol. 13, No. 4, pp. 273-276, DOI: 10.21046/2070-7401-2016-13-4-273-276.

7. U. Sultangazin, N. Muratova, P. Doraiswamy, A. Terekhov, Estimation of weed infestation in spring crops using MODIS data, Proceedings of IGARSS'03, Toulouse, 2003, Vol. 1, pp. 392-394.

8. N. Muratova, A. Terekhov, Estimation of spring crops sowing calendar dates using MODIS in Northern Kazakhstan, Proceedings of IGARSS'04, Anchorage, 2004, Vol.6, pp. 4019-4020.

9. L. Spivak, I. Vitkovskaya, M. Batyrbayeva, A. Terekhov, The experience of land cover change detection by satellite data, Frontiers of Earth Science, 2012, Vol. 6, No. 2, pp. 140-146. DOI: 10.1007/s11707-012-0317-z.

10. A. G. Terekhov, I. T. Pak, S. A. Dolgikh, Hydrology monitoring of Kapchagay reservoir on river Tekes (China's part of river Ile basin) based on LANDSAT 5,7,8 data and DEM batymetry, Sovremennye problemy distantsionnogo zondirovaniya Zemli iz kosmosa, 2015, Vol. 12, No. 6, pp. 174-182.

11.A. G. Terekhov, A. A. Pak, Influence of the Kapshagay reservoir (China) refill on transboundary River Ile runoff and satellite-based forecasting, Sovremennye problemy distantsionnogo zondirovaniya Zemli iz kosmosa, 2019, Vol. 16, No. 4, pp. 298-302, DOI: 10.21046/2070-7401-2019-16-4-298-302.

12. A. G. Terekhov, N. I. Ivkina, N. R. Yunicheva, I. S. Vitkovskaya, A. G. Yeltay, Changes in seasonal snow cover in dry steppes and semi-deserts of Kazakhstan: an example using data between 2001 and 2019 from Emba River basin, Sovremennye problemy distantsionnogo zondirovaniya Zemli iz kosmosa, 2020, Vol.17, in press. 